\title{
Investigation of operating costs at an urban wastewater treatment plant
}

\section{Bir evsel atıksu arıtma tesisinde işletme maliyetlerinin incelenmesi}

\author{
Süreyya ALTIN¹, Ahmet ALTIN¹, Sevcan DOĞRU1
}

\section{ABSTRACT}

Objective: In recent years, thanks to improving technology and economic conditions urban wastewater treatment plant (WWTP) constructions have accelerated. Wastewater characteristics and treatment requirements usually are taken into account for the planning of wastewater treatment plants. But, operation costs also are important as the least investment costs for the sustainability of the treatment plant. The performance of equipment used in the treatment units during the operation is important as well as the wastewater characteristics for the accomplishment and sustainability of wastewater treatment plants designed. In this study, it has been aimed investigation as detailed of operation costs of an urban wastewater treatment plant that is designed as an advanced biological treatment for a settlement of 108.000 populations, and determination of real operation data.

Methods: Electricity consumption, the chemical agent used, staff number, maintenance-repair, and other expenses at each unit of the plant have been considered at the operation cost analysis of the aforementioned plant. Firstly, the individual operating costs of each treatment unit were calculated according to its running conditions and equipment properties.

\section{ÖZET}

Amaç: Son yıllarda gelișen teknoloji ve ekonomi koșulları sayesinde kentsel atıksu arıtma tesisi (AAT) inșaatları hızlanmıștır. Atıksu arıtma tesislerinin planlanmasında genellikle atıksu özellikleri ve arıtma gereksinimleri dikkate alınmaktadır. Ancak, arıtma tesisinin sürdürülebilirliği için en az yatırım maliyeti kadar ișletme maliyetleri de önem arz etmektedir. Arıtma ünitelerinde ișletme sırasında kullanılan ekipmanın performansı ve atık su arıtma tesislerinin başarısı ve sürdürülebilirliği için atık su özellikleri oldukça önemlidir. Bu çalıșmada, 108.000 nüfuslu yerleșim için tasarlamıș ileri bir biyolojik arıtma olarak tasarlanan kentsel atıksu arıtma tesisinin işletme maliyetlerinin ayrıntılı incelenmesi ve gerçek işletme verilerinin belirlenmesi amaçlanmıştır.

Yöntem: Söz konusu arıtma tesisinin ișletme maliyet analizinde elektrik tüketimi, kullanılan kimyasal ajan, personel sayısı, bakım-onarım ve tesisin her birimindeki diğer giderler dikkate alınmıștır. Ilk olarak, her arıtma ünitesinin bireysel işletme maliyetleri çalıșma koșullarına ve ekipman özelliklerine göre hesaplanmıștır. Ardından toplam ișletme maliyetleri günlük, aylık ve yıllık olarak belirlenmiștir.

'Zonguldak Bülent Ecevit University, Department of Environmental Engineering, Zonguldak

\footnotetext{
İletişim / Corresponding Author : Ahmet ALTIN

Zonguldak Bülent Ecevit Üniversitesi, Çevre Mühendisliği Bölümü, Farabi Kampüsü Zonguldak - Türkiye

E-posta / E-mail : a.altin.16@gmail.com
}

DOI ID : 10.5505/TurkHijyen.2020.74875

Altın S, Altın A, Doğru S. Investigation of operating costs at an urban wastewater treatment plant.

Turk Hij Den Biyol Derg, 2020; 77(EK4: Su ve Sağlık): 49-56 
Then, total operating costs were determined daily, monthly and yearly. According to determined operating costs, treatment costs both per volume and pollution load of wastewater were calculated. Lastly, these data were compared with the previous studies.

Results: The total operating costs of the plant have been calculated as about 592740 \$/year. The electricity requirement is $42 \%$ of the total operating costs. The highest operating cost in the plant is at the activated sludge unit and calculated as 223437 \$/year. It is determined that total energy requirements are 0.88 $\mathrm{kWh}, 58.75 \mathrm{kWh}$ and $2.22 \mathrm{kWh}$ for per $\mathrm{m}^{3}$ wastewater, per person, and per kg COD (Chemical Oxygen Demand), respectively.

Conclusion: The operating costs and total costs calculated in this study are compatible with the costs obtained from previous studies. Generally, it may be said that operating costs in the WWTP are most affected by electricity and staff expenses. Since this study was conducted on a medium-sized WWTP, the energy costs of the equipment in the activated sludge unit have a higher percentage than other expenses.

Key Words: Operating costs, urban wastewater treatment plant, energy requirement for WWTPs
Belirlenen ișletme maliyetlerine göre, atık suyun hem hacim hem de kirlilik yükü bașına arıtma maliyetleri hesaplanmıștır. Elde edilen sonuçlar önceki çalıșmalar ile karșılaștırılmıștır.

Bulgular: Tesisin toplam ișletme maliyeti yaklașık 592740 \$ / yıl olarak hesaplanmıștır. Elektrik ihtiyacı toplam ișletme maliyetinin \%42'sidir. Tesisteki en yüksek ișletme maliyeti aktif çamur ünitesindedir ve 223437 \$ / yıl olarak hesaplanmıștır. Toplam enerji ihtiyacının $\mathrm{m}^{3}$ atıksu, kiși için ve $\mathrm{kg}$ COD (Kimyasal Oksijen İhtiyacı) başına sırasıyla 0.88 kWh, 58.75 kWh ve $2.22 \mathrm{kWh}$ olduğu belirlenmiștir.

Sonuç: Bu çalıșmada hesaplanan işletme maliyetleri ve toplam maliyetler, önceki çalıșmalardan elde edilen maliyetlerle uyumludur. Genel olarak, AAT içerisindeki işletme maliyetlerinin daha çok elektrik ve personel giderlerinden etkilendiği söylenebilir. Bu çalıșmanın Orta ölçekli bir AAT üzerine yapılması nedeniyle, aktif çamur ünitesindeki ekipmanların enerji maliyetleri diğer giderlere göre daha yüksek yüzdeye sahiptir.

Anahtar Kelimeler: İșletme maliyetleri, kentsel atıksu arıtma tesisi, atıksu arıtma tesisleri için enerji ihtiyacı

\section{INTRODUCTION}

In the scope of pollution control in natural water sources and sustainable environment studies, the count of wastewater treatment plants in the developed and developing countries has quite increased in recent years. Advanced biological treatment processes are usually preferred for urban wastewater treatment (UWWTP). Energy requirements of the UWWTPs' change according to the design criteria, equipment choosing and a population of the settlement area. It is estimated that electric energy used by WWTPs' is corresponding to $3 \%$ and $1 \%$ of total national electricity consumption in industrialized countries and in the European countries, respectively $(1,2)$.

Renewed of old infrastructure systems for numerous settlement areas, population rising, and discharge limits decreased can be reason increasing of energy required for WWTP in the near future. Until now, while wastewater plants are designed, the energy costs used at the plant have not taken into account. Therefore, measures for energy saving 
have been not planned at the municipal WWTPs. However, considering the increasing energy costs, the importance of operating costs and energy consumption of the treatment plants have also increased.

No doubt, it is not easy to determine comprehensive information of cost in relation to WWTPs or to obtain benchmarking information for different treatment processes. Maintaining and repairing equipment, the volume of water treated, removed contaminants and age of the plant are very important on the operating costs of the plants (3). Nevertheless, doing a detailed energy cost analysis at the WWTPs is necessary and so important at providing useful data for the design of new WWTP both now and in the future.

Much research has shown that the capacity of WWTPs is a prominent factor at the cost of operating and maintaining activities. Also, the age of the WWTPs, treatment technology used, and level of treatment affect operating costs. Until this time, WWTPs designed considering the provide discharge requirements. However, according to the last researches, while WWTPs are planned, not only the first investment cost and choosing of treatment process which is most suitable from the technical aspect but also economic analysis of operating and maintenance costs are very important.

While new WWTPs are planned, it must be considered sufficient treatment of wastewater, choosing equipment with energy-saving, implementing periodical maintain of equipment, and using probable alternative energy sources. Also, it must be determined own energy production potential and energy-saving opportunities of the plant (3). Energy consumption may be decreased by routine equipment maintenance (4), establishing the management system in real-time (5), and developing special practices for processes consuming high energy. Furthermore, different renewable energy sources as suitable to the properties and running conditions of WWTP may be developed and used (6). Instead of the drying beds utilizing sun energy, greenhouse type dryers that solar energy is used more effectively may be preferred. In case producing electrical energy by biogases generated from anaerobic digestion unit, WWTPs may self-support from energy aspect during the year. Moreover, sometimes, the energy generation potential of WWTPs may be more than that is required for WWTPs (7).

In this study, it has been aimed at the investigation as detailed of the operation costs of an urban wastewater treatment plant. WWTP investigated in this study is an advanced biological wastewater treatment plant. For this purpose, firstly, electricity energy consumed by equipment at the WWTP was determined by using daily running time and power information on equipment in all treatment units, and electricity costs were calculated. Then, other operating costs (chemical costs, maintenancerepair costs, etc.) were determined. Last, the total operating costs for the WWTP were calculated by considering also other operating costs.

\section{PROPERTIES OF THE WASTEWATER TREATMENT PLANT}

In this study, the urban wastewater treatment plant that is performed operating costs analysis is a medium scale WWTP. Advanced biological treatment is implemented in this treatment plant. The design flow rate of the plant is $34128 \mathrm{~m}^{3} /$ day. The sewerage system of the city consists of nine pumping stations, $14118 \mathrm{~m}$ non-pressure and $46112 \mathrm{~m}$ pressure transmission lines. In the city, there is a deepsea discharge line of $640 \mathrm{~m}$ for the treated water discharge system. The WWTP consists of physical, biological, and sludge treatment units (Figure 1).

Physical treatment units are screens, grit and oil/ grease holders, and primary clarifiers. The biological treatment unit has included an activated sludge reactor, secondary clarifiers. Sludge treatment unit in the plant consists of sludge thickener, anaerobic digester, sludge retention tank, sludge conditioner tank, sludge dewatering tank. 


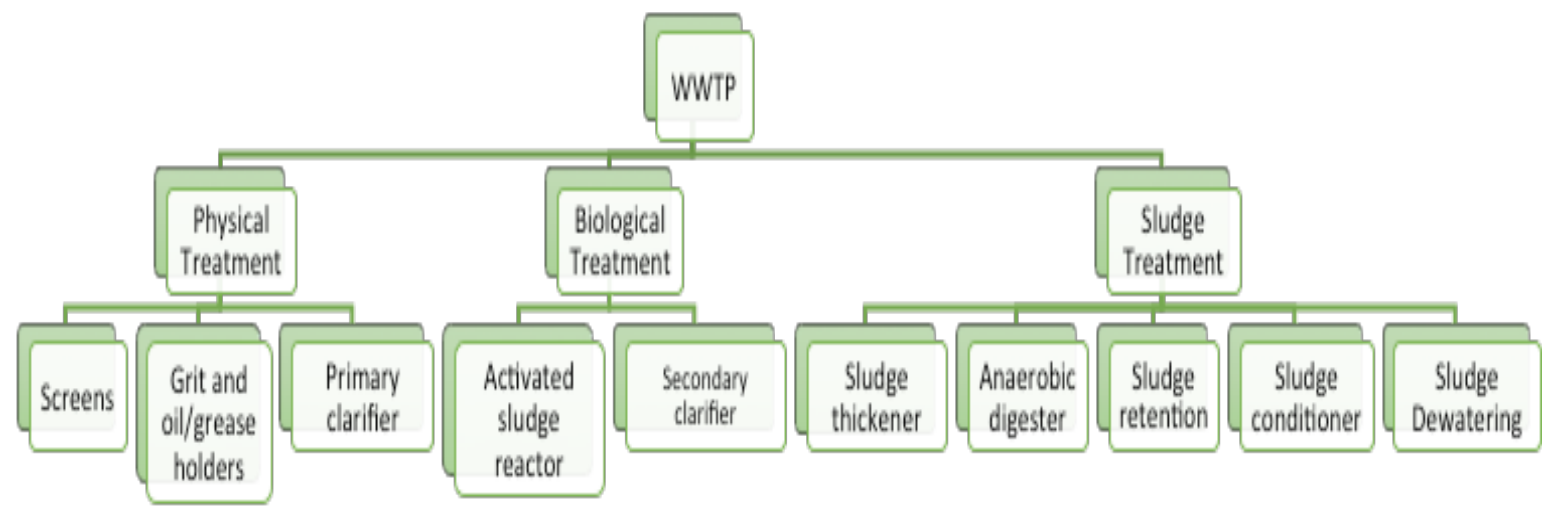

Figure 1. Units of urban wastewater treatment plant.

\section{OPERATING COSTS OF THE WASTEWATER TREATMENT PLANT}

While operating costs of the WWTP is determined, energy consumptions of all equipment (pumps, mixers, blowers, etc.) have been considered. For calculating energy consumptions, power information of equipment at the plant has been used. Daily working time at the plant has been learned from responsible personnel of the facility. For reaching total operating costs, the other operating expenses in the WWTP have been obtained from documents of the plant.

For determination of wastewater flowrate and pollution loads arriving at the plant; the population of the city assumed as 108000 for 2017, and water amount discharging as $181 \mathrm{~L} /$ per person a day. So, the wastewater amount of the plant was calculated as 19 $548 \mathrm{~m}^{3} /$ day via assuming collected all wastewater in the city center by the sewerage system, and pollution loads of the wastewater were found as $400 \mathrm{mg}$ COD, $230 \mathrm{mg}$ BOD (Biochemical Oxygen Demand) and 150 mg SSM (Scale Structured Sheet Media) for per liter of the wastewater. After the total operating costs of the plant were calculated, consumed energy per liter of wastewater and per person were determined according to the flow rate of wastewater coming to WWTP. Similar calculations were also performed per pollution loads.

\section{ENERGY CONSUMPTIONS OF TREATMENT PLANT UNITS}

The energy consumptions and calculated energy costs of each treatment unit in the plant are presented in Table 1.

According to calculations performed by using obtained data from the plant, the highest electrical energy (5 $636184 \mathrm{kWh} /$ year) has been consumed at the biological treatment units. This value has been corresponding to $89 \%$ of the total energy necessity in the plant.

The biological treatment unit (activated sludge tank and secondary clarifiers) consists of 3 blowers that run 24 hours in a day, 2 scraper bridges, 2 oil pumps, 3 back return pomp, and 3 excess sludge pump running one hour in a day. Both the number and power capacity of the equipment in the unit is higher than in other units. Blowers use $93 \%$ of electricity consumption in the units (Figure 2). Electricity consumption of blowers was determined as 15 $441 \mathrm{kWh} /$ day, that is, $83 \%$ of the total electricity 
Table 1. Energy consumption and cost of this energy for each treatment unit

\begin{tabular}{lccr}
\multicolumn{1}{c}{ Treatment Units } & Energy Consumptions $(\mathrm{kWh} /$ year) & Costs (TL/year) & Costs(\$/year*) \\
\hline Screenings & 30660 & 6564 & 1216 \\
Grit and oil/grease units & 191581 & 41012 & 7595 \\
Primary clarifier & 45289 & 9695 & 1795 \\
Biological treatment units & $\mathbf{5} 636184$ & $\mathbf{1} 206560$ & 223437 \\
Sludge thickener & 2920 & 625 & 116 \\
Anaerobic digester & 293898 & 62915 & 11651 \\
Sludge conditioner & 144540 & 30942 & 5730 \\
Total & 6345072 & 1358313 & 251540 \\
\hline
\end{tabular}

* it is assumed as $1 \mathrm{TL}=5.40 \mathrm{~S}$

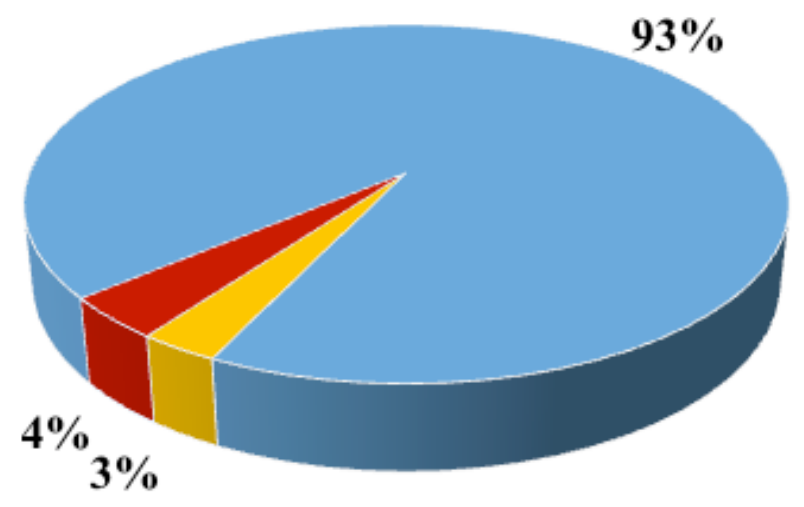

\section{blowers others aumps}

Figure 1. Electricity consumption percentages of some equipment in the activated sludge unit

consumption of the plants. A previous study has been expressed that the energy requirements of the blowers in the conventional activated sludge process is between 55 and $70 \%$ of the total electricity consumption of the WWTP (8). In the other study in Italy, this rate has defected as $50 \%$ for a large-scale biological treatment plant (9). Considering these results, it may be said, by increasing of WWTP scale, the place of blowers in total electricity consumption is decreased.
Numerous pumps may be used for different aims in the WWTPs. The pumps are equipment that requiring the most electricity energy secondly after the blowers. In this study, electricity used by pumps found as $10 \%$ of total electricity consumption in the plant. In another study, this percentage was given as $15 \%$ of total electricity consumption (8).

\section{OTHER OPERATING COSTS AT THE TREATMENT PLANT}

Apart from the energy costs of equipment at the 
Table 2. The annual other operating costs at the treatment plant

\begin{tabular}{|c|c|c|c|}
\hline Expense Kind & Related unit & Costs (TL/year) & Costs $(\$ /$ year*) \\
\hline \multirow{2}{*}{ Chemical material } & Sludge dewatering (cationic polymer) & 133567 & 24735 \\
\hline & Laboratory & 9654 & 1788 \\
\hline \multirow{5}{*}{ Maintenance-repair } & Screens & 7339 & 1359 \\
\hline & Blower & 58343 & 10804 \\
\hline & Pump & 101904 & 18871 \\
\hline & Periodic control of equipment & 4318 & 800 \\
\hline & Other repair & 54750 & 10139 \\
\hline Staff & & 1460000 & 270370 \\
\hline Consultancy service procurement & & 12602 & 2334 \\
\hline Total & & 1842477 & 341200 \\
\hline
\end{tabular}

${ }^{*}$ it is assumed as $1.00 \mathrm{TL}=5.40 \$$

treatment plant, there are operating costs, such as the chemicals used, maintenance and repair costs, and personnel costs. The other annual operating costs in the treatment plant are given in Table 2.

It seems from Table 2 that staff expenditures are higher than related to other expenses. The maintenance costs of the pumps cover a large portion amount of maintenance-repair expenses. Percentages of all expenses at the WWTP according to total annual operation costs have been given in Figure 3.

In a previous study, energy consumption cost had been expressed as to can be between 25 and 40\% of total operation cost (8). In this study, electricity consumption cost has been calculated as $42 \%$ of the total operation cost. This rate may be higher than $50 \%$, according to increases in electricity prices (10). The energy requirements of the equipment at the activated sludge unit corresponds to an important percentage of operating costs in small and medium scale treatment plants. However, as the scale of the treatment plant grows, this rate may reduce due to increase staff and maintenance-repair costs (9).

As take account with percentages of expense types affected by the operating cost, the expenses can be ordered as staff>electricity>maintenancerepair>chemical material (Figure 3 ). In another study,

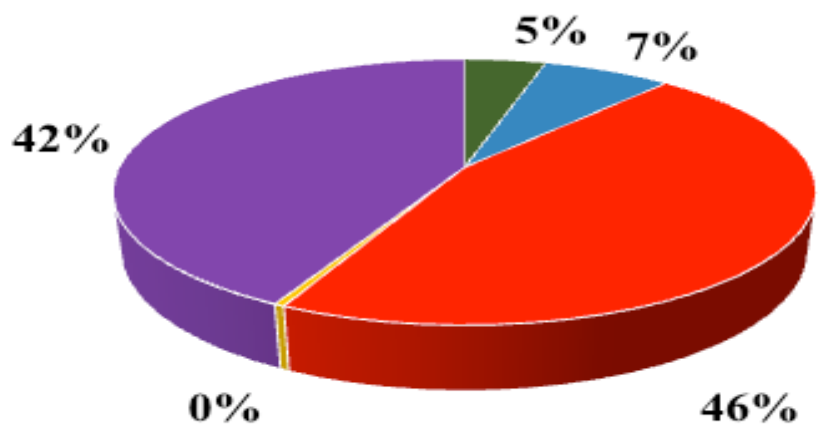

- Chemical Material

- Maintenance-repair

- Staff

- Consultancy

- Electricity

Figure 3. Percentage of the expenses which constituent total annual operating costs. 
similar results found for extended aeration treatment processes (11). Differently, the staff costs in our study were determined higher than the electricity costs.

\section{TOTAL OPERATING COSTS}

Unit costs have been determined for an annual flow-rate of treated water, pollution loads and population served and results have given in Table 3. Electricity consumption may be variated between approximately $0.3-2.1 \mathrm{kWh} / \mathrm{m}^{3}$ for treated wastewater (9). In this study, electricity consumption has been calculated as $0.88 \mathrm{kWh} / \mathrm{m}^{3}$ for a unit volume of wastewater. This value is consistent with the value expected for a medium-sized WWTP and its equivalent population (10). If the capacity of WWTP is increased or the electricity requirement is supported by its selfelectricity production, this cost will decrease (10).

According to the COD pollution load, the consumed energy was calculated as $2.22 \mathrm{kWh} / \mathrm{kg}$ COD. This value is consistent with some previous studies (12, $13)$, but it is slightly higher than other studies $(9,14)$. Considering that the pollution loads do not change much for domestic wastewater, this difference can

Table 3. Treatment costs for a unit volume of wastewater, per pollution loads and per person

\begin{tabular}{lccc}
\hline & Electricity consumption & $\begin{array}{c}\text { Operating costs for } \\
\text { electricity consumption }\end{array}$ & Total operation costs \\
\hline *for per person & $58.75 \mathrm{kWh} /$ person & $2.33 \$ /$ person & $5.487 \$ /$ person \\
** for treated & $0.88 \mathrm{kWh} / \mathrm{m}^{3}$ & $0.035 \$ / \mathrm{m}^{3}$ & $0.081 \$ / \mathrm{m}^{3}$ \\
wastewater & $2.22 \mathrm{kWh} / \mathrm{kgCOD}$ & $0.089 \$ / \mathrm{kgCOD}$ & $0.224 \$ / \mathrm{kgCOD}$ \\
COD & $3.86 \mathrm{kWh} / \mathrm{kgBOD}$ & $0.154 \$ / \mathrm{kgBOD}$ & $0.361 \$ / \mathrm{kgBOD}$ \\
BOD & $5.93 \mathrm{kWh} / \mathrm{kgSSM}$ & $0.235 \$ / \mathrm{kgSSM}$ & $0.553 \$ / \mathrm{kgSSM}$ \\
\hline SSM & &
\end{tabular}

* The population served is 108000 people. Total annual cost (electricity consumption + other expenses) is used to calculate the operating cost per person.

** The total wastewater volume was determined by assuming that the daily water consumption per person is 0.181 $m^{3} /$ person $\left(0.181 * 365 * 108000=7135020 \mathrm{~m}^{3} /\right.$ year $)$.

be attributed to the treatment method and the type of equipment, energy production, and facility management in the plant.

\section{CONCLUSION}

In the scope of this study, the operating costs and total costs calculated in this study are compatible with the costs obtained from previous studies. Generally, it may be said that operating costs in the WWTP are most affected by electricity and staff expenses. Because of the study on a medium-sized WWTP, the operating costs due to the energy needs of equipment in the activated sludge unit has a higher percentage compared to other expenses.

In the treatment plants that are present to these characteristics may be decreased energy requirement by using suitable control systems and preferring more efficient equipment in the activated sludge aeration process. In addition, energy consumptions of the treatment plant may be decreased by constantly monitoring and improving the performance of all equipment in the production and saving of energy in the plant. The quality and stability of chemical solutions used, and optimization of both staff and operation expenses also affects to operation cost of the plant, positively. 


\section{REFERENCES}

1. Frison N, Chiumenti A, Katsou E, Malamis S, Bolzonella D, Fatone F. Mitigating off-gas emissions in the biological nitrogen removal via nitrite process treating anaerobic effluents. J Clean Prod, 2015; 93:126-33.

2. Longo S, d'Antoni BM, Bongards M, Chaparro A, Cronrath A, Fatone F, et al. Monitoring and diagnosis of energy consumption in wastewater treatment plants. a state of the art and proposals for improvement. Appl Energ, 2016; 179:1251-68.

3. Hernandez-Sancho F, Molinos-Senante M, \& Sala-Garrido R. Cost modelling for wastewater treatment processes. Desalination 2011; 268(13):1-5.

4. Brandt MJ, Middleton RA, Wang S. Energy efficiency in the water industry: a compendium of best practices and case studies-global report. London: IWA Publishing, 2012.

5. EPA. Energy efficiency in water and wastewater facilities, Local Government Climate and Energy Strategy Guides, EPA-430-R-09-038. Washington DC: United States Environmental Protection Agency, 2013.

6. Chae KJ, Kang J. Estimating the energy independence of a municipal wastewater treatment plant incorporating green energy resources. Energ Convers Manage, 2013; 75:66472.

7. Shizas I, Bagley DM. Experimental determination of energy content of unknown organics in municipal wastewater streams. J Energ Eng, 2004; 130(2):45-53.
8. Tchnobanoglous G, Bourton FL, Stensel HD. Wastewater engineering, treatment and reuse. 4th ed. Hongkong: Metcalf \& Eddy, Inc. 2003.

9. Panepinto D, Fiore S, Zappone M, Genon G, \& Meucci L. Evaluation of the energy efficiency of a large wastewater treatment plant in Italy. Appl Energ 2016; 161: 404-11.

10. Trapote A, Albaladejo A, Simón P. Energy consumption in an urban wastewater treatment plant: the case of Murcia Region (Spain). Civ Eng Environ Syst, 2014; 31(4):304-10.

11. Vera I, Sáez K, Vida G. Performance of 14 fullscale sewage treatment plants: comparison between four aerobic technologies regarding effluent quality, sludge production and energy consumption. Environ Technol, 2013; 34(15):226775.

12. Foladori P, Gatti GB, Groff M. Analisi ed efficientamento energetico dell'impianti di depurazione di Folgaria (TN). Atti della $49^{\circ}$ Giornata di Studio di Ingegneria Sanitaria Ambientale, Ottobre, 23, Genova. 2013.

13. Guglielmi L, Belli R. Riduzione dei consumi energetici nell'impianto di depurazione di Mancasale (RE), Atti della $49^{\circ}$ Giornata di Studio di Ingegneria Sanitaria Ambientale, Ottobre, 23, Genova. 2013.

14. Frijns J, Hofman J, Nederlof M. The potential of (waste) water as energy carrier. Energy Convers Manag, 2013; 65:357-63. 